\title{
Analisis faktor - faktor yang mempengaruhi produksi pada industri rumah tangga (studi kasus : industri kerupuk udang di Desa Lambur Luar Kecamatan Muara Sabak Timur Kabupaten Tanjung Jabung Timur)
}

\author{
Trisa Mushandry Pratiwi; *Hardiani; Adi Bhakti
}

Prodi Ekonomi Pembangunan, Fak Ekonomi dan Bisnis, Universitas Jambi

E-mail korespondensi: dian_nst@yahoo.com

\begin{abstract}
The purpose of this study is (1) To analyze the socioeconomic characteristics of Producers in the Shrimp Crackers Home Industry in the Village of Lambur Luar Tanjung Jabung Timur Regency, (2) To analyze the effect of capital, labor, prices and raw materials on production in the Home Industry Shrimp Crackers in Lambur Luar Village, Tanjung Jabung Timur Regency. The results showed that all independent variables (capital, labor, prices and raw materials) affected the production of the shrimp cracker industry in Lambur Luar Village. Judging from the test results obtained by the coefficient of determination $\left(R^{2}\right)$ of 0.963460. This is aimed at capital, labor, prices and raw materials able to influence production by 96.34 percent and the remaining 3.66 percent for other variables not included in this study. Whereas if tested partially, capital, labor, price and raw material variables have a positive and significant effect on production in the shrimp cracker industry in Lambur Luar Village.
\end{abstract}

Keywords : Production, capital, labor, price and raw materials.

\begin{abstract}
Abstrak
Tujuan dari penelitian ini adalah (1) Untuk menganalisis karakteristik sosial ekonomi Produsen pada Industri Rumah Tangga Kerupuk Udang di Desa Lambur Luar Kabupaten Tanjung Jabung Timur, (2) Untuk menganalisis pengaruh modal, tenaga kerja, harga dan bahan baku terhadap produksi pada Industri Rumah Tangga Kerupuk Udang di Desa Lambur Luar Kabupaten Tanjung Jabung Timur.

Hasil penelitian menunjukkan bahwa seluruh variabel independen (modal, tenaga kerja, harga dan bahan baku) berpengaruh terhadap produksi pada industri kerupuk udang di Desa Lambur Luar. Dilihat dari hasil pengujian diperoleh nilai koefisien determinasi $\left(R^{2}\right)$ sebesar 0.963460 . Hal ini menujukan modal, tenaga kerja, harga dan bahan baku mampu mempengaruhi produksi sebesar 96,34 persen dan sisanya 3,66 persen variabel lainnya yang tidak termasuk dalam penelitian ini. Sedangkan jika diuji secara parsial, varibael modal, tenaga kerja, harga dan bahan baku berpengaruh positif dan signifikan terhadap produksi pada industri kerupuk udang di Desa Lambur Luar.
\end{abstract}

Kata kunci : Produksi, modal, tenaga kerja, harga dan bahan baku

\section{PENDAHULUAN}

Sektor industri memiliki pengaruh ganda terhadap perekonomian nasional secara keseluruhan dimana semakin berkembangnya sektor industri maka dapat merangsang tumbuhnya industri-industri baru dan akan membuka kesempatan kerja yang semakin 
luas. Selain itu sektor industri merupakan salah satu sektor ekonomi yang memiliki multiplier effects yang sangat dominan karena dengan didirikannya sektor industri maka akan tumbuh berbagai industri lain dan kegiatan ekonomi lainnya yang mengikuti tumbuhnya sektor industri.

Usaha memperluas kesempatan kerja sangat diperlukan guna mengatasi masalah pengangguran. Kebijakan semua sektor ekonomi harus dirangkai dengan peningkatan partisipasi angkatan kerja sesuai dengan kondisi dan potensi ketenagakerjaan yang tersedia. Kebijakan ini harus didukung dengan upaya meningkatkan kualitas angkatan kerja berdasrkan pendidikan dan keterampilan yang memadai serta peningkatan dalam produksi.

Sektor industri Indonesia merupakan salah satu sektor yang mulai memiliki peran penting dalam perekonomian Indonesia. Hal ini terbukti dengan terus mengikatnya kontribusi sektor industri terhadap PDB dan penciptaan tenaga kerja di Indonesia. Kegiatan pembangunan industri bertujuan untuk menyediakan lapangan kerja dan meningkatkan devisa Negara (Ginting, 2009).

Kabupaten Tanjung Jabung Timur merupakan salah satu kabupaten kota di Provinsi Jambi, wilayahnya merupakan wilayah perairan laut, sehingga masyarakatnya sebagian besar berprofesi menjadi nelayan. Kepala keluarga sebagai nelayan dan ibu-ibu sekitar memanfaatkan hasil tangkapan udang atau ikan menjadi industri rumah tangga kerupuk. Industri kerupuk udang merupakan salah satu industri rumah tangga di Desa Lambur Luar Kabupaten Tanjung Jabung Timur. Industri ini pada umumnya dikelola oleh sebagian anggota keluarga atau rumah tannga, dan sebagian lagi dikelola oleh pengusaha yang membentuk industri kecil. Disamping itu produksi juga diartikan sebagai proses kombinasi material-material dan kekuatan-kekuatan (input, faktor, sumberdaya, atau jasa-jasa produksi) dalam pembuatan suatu barang atau jasa (output atau produk) (Aris, 2012).

Pemerintah Kabupaten Tanjung Jabung Timur selalu berupaya meningkatkan pendapatan perekonomian masyarakat khususnya para pelaku industri kecil dan menengah melalui kegiatan pembinaan berupa kegiatan pelatihan, sosialisasi dan pembinaan langsung ke para pengrajin. Pada tahun 2018 di Kabupaten Tanjung Jabung Timur telah terbentuk organisasi pengrajin industri kecil dan menengah (IKM) yang merupakan suatu wadah bagi para pengrajin untuk berkomunikasi dan bertukar informasi dalam rangka peningkatan kualitas dan pemasaran produk, selain itu juga organisasi tersebut sebagai perpanjangan tangan pemerintah daerah khususnya instansi terkait dalam kegiatan pembinaan IKM.

Pada tahun 2018 Pemerintah Kabupaten Tanjung Jabung Timur memiliki beberapa program kerja yang bertujuan meningkatkan perekonomian masyarakat dengan mengembangkan potensi - potensi sumber daya alam melalui Industri Kecil dan Menengah (IKM). Pemerintah Kabupaten Tanjung Jabung Timur menitik beratkan pada pengembangan produk unggulan hasil Pengolahan Perikanan dan Olahan Laut seperti Kerupuk udang.

Jumlah Industri Kecil dan Menengah (IKM) di Kabupaten Tanjung Jabung Timur sebanyak 403 unit, dimana jumlah IKM terbanyak berada di Kecamatan Muara Sabak Timur sebanyak 71 unit, diikuti Kecamatan Geragai sebanyak 56 unit. Mayoritas IKM memiliki usaha penghasil produk olahan hasil laut Kerupuk udang, kerupuk ikan, dan kerupuk kayu api.

Berdasarkan data yang di peroleh dari Dinas Perindustrian dan Perdagangan Kabuapten Tanjung Jabung Timur tahun 2018 bahwa industri Kerupuk udang yang 
terdaftar dalam Kelompok sentra industri kecil dan menengah Kabuapten Tanjung Jabung Timur terbanyak yaitu pada Kecamatan Muara Sabak Timur yaitu sebanyak 24 industri. Inilah alasan penulis untuk mengambil sampel pada 1 Desa di Kecamatan Muara Sabak Timur. Desa Lambur Luar merupakan Desa yang ada di Kecamatan Muara Sabak Timur, hal ini yang menjadi alasan penulis untuk mengambil sampel dari desa tersebut karena merupakan kecamatan yang memiliki Industri kerupuk terbanyak.

Industri kecil pengolahan makanan hasil perikanan merupakan industri yang mengalami perkembangan dari tahun ketahun, salah satunya industri kerupuk olahan udang. Lokasi industri kerupuk olahan udang dan ini terdapat pada Kecamatan Muara Sabak Timur Kabupaten Tanjung Jabung Timur, tetapi tidak menutup kemungkinan di daerah lain berkembang juga industri yang sama.

Selain bahan baku yang tersedia dari daerah itu sendiri, perkembangan hasil olahan udang ini juga di pengaruhi modal, tenaga kerja, harga dan bahan baku. Dengan jumlah modal, tenaga kerja dan bahan baku serta harga kerupuk yang berbeda-beda di tiap unit usaha. Konsumen selalu mengharapkan produsen atau perusahaan memberikan harga yang terjangkau untuk tiap produknya. Dan juga konsumen berharap untuk mendapatkan kualitas produk yang terbaik.

Menurut (Bangun, 2010) dalam jangka pendek, untuk menghasilkan barang dan jasa salah satu input yang digunakan tetap sedangkan penggunaan input lain berubah. Oleh karena itu dalam jangka pendek biaya produksi dapat diklasifikasi kedalam biaya tetap (fixed cost/FC), biaya variabel (variabel cost/VC), dan biaya Total (total cost/TC).

Sementara itu, pembangunan industri kecil dan menengah akan lebih diperhatikan karena mengemban misi menciptakan pemerataan kesempatan kerja dan berusaha melestarikan seni budaya, Modernisasi masyarakat desa dan kota serta memperkuat struktur industri, dan meningkatkan ekspor nasional. Oleh karena itu pembinaan dan pengembangan industri kecil dan menengah diharapkan mampu mengatasi masalah-masalah yang dihadapi dan diharapkan dapat berkembang ke arah yang lebih maju dan mandiri. Adapun permasalahan utama yang dihadapi para pengusaha kerupuk udang saat ini adalah mengenai kenaikan harga bahan baku setiap tahunnya untuk memproduksi kerupuk udang tersebut. Harga tepung terigu dan udang yang menjadi bahan dasar untuk membuat kerupuk udang ini di pasaran semakin mahal, kenaikan ini sangat memberatkan bagi para pengusaha kerupuk yang sebagian besar dari mereka memiliki modal yang pas-pasan untuk memproduksi kerupuk udang.

Dalam teori ekonomi diambil pula satu asumsi dasar mengenai sifat dari fungsi produksi. Yaitu fungsi produksi dari semua produksi dimana semua produsen dianggap tunduk pada suatu hukum yang disebut : The Law of Diminishing Returns. Hukum ini mengatakan bahwa bila satu macam input ditambah penggunaannya sedang input-input lain tetap maka tambahan output yang dihasilkan dari setiap tambahan satu unit input yang ditambahkan tadi mula-mula menarik, tetapi kemudian seterusnya menurun bila input tersebut terus di tambah (Boediono, 2013).

Dengan adanya tenaga kerja kegiatan produksi akan cepat terselesikan dengan baik, artinya faktor tenaga kerja sangat dibutuhkan dalam proses kegiatan produksi. Kegiatan produksi akan berhenti jika tenaga kerja yang diperlukan mengalami gangguan, sehingga berdampak pada penjualan yang akan diterima perusahaan atau industri tersebut (Kardiman, 2003).

Biaya tenaga kerja adalah biaya yang harus dikeluarkan menggunakan tenga kerja per orang per satuan waktu. Harga tenaga kerja adalah upahnya (per jam atau per hari). Bagi ekonomi upah pekerja adalah biaya eksplisit dengan asumsi upah yang dibayarkan adalah sama besar dengan upah yang diterima tenaga kerja bila bekerja di 
tempat yang lain. Asumsi ini terpenuhi di pasar tenaga kerja persaingan sempurna (Rahardja dan Manuruntgm 2008).

Harga merupakan sejumlah nilai yang ditukarkan konsumen dengan manfaat dari memiliki atau menggunakan produk atau jasa yang nilainya ditetapkan oleh pembeli atau penjual melalui tawar menawar, atau ditetapkan oleh penjual untuk satu harga yang sama terhadap semua pembeli. Kotler dan Keller (2012), menyatakan harga harus mencerminkan nilai konsumen bersedia membayar harga dibandingkan harus mencerminkan hanya biaya pembuatan produk atau memberikan layanan. Artinya harga merupakan sejumlah uang yang dibutuhkan atau ditukarkan ke konsumen untuk mendapatkan atau memiliki suatu barang yang memiliki manfaat serta penggunaannya.

Faktor produksi tenaga kerja adalah segala kegiatan jasmani maupun rohani yang ditujukan untuk kegiatan produksi. Pemanfaatan tenaga kerja dalam proses produksi haruslah dilakukan secara manusiawi, artinya perusahaan pada saat memanfaatkan tenaga kerja dalam proses produksinya harus menyadari bahwa kemampuan mereka ada batasnya, baik tenaga kerja maupun keahliannya. Selain itu juga perusahaan harus mengikuti peraturan yang dikeluarkan pemerintah dalam menetapkan besaran gaji tenaga kerja. Posisi faktor tenaga kerja sangat dominan jika dibandingkan dengan faktor produksi lainnya dalam suatu proses produksi (Kardiman 2003). Faktor produksi tenaga kerja berpengaruh positif terhadap suatu industri karena faktor tenaga kerja sangat dibutuhkan dalam proses kegiatan produksi.

Investasi, yang lazim disebut juga dengan istilah penanaman modal atau pembentukan modal. Dengan demikian istilah investasi dapat diartikan sebagai pengeluaran atau pengeluaran penanaman-penanaman modal atau perusahaan untuk membeli barang barang modal dan perlengkapan-perlengkapan produksi untuk menambah kemampuan memproduksi barang-barang dan jasa-jasa yang tersedia dalam perekonomian (Sukirno, 2010).

\section{METODE}

Metodologi penelitian yang digunakan adalah metode survei. Dalam penelitian ini, peneliti meneliti karakteristik untuk membuktikan hubungan sebab akibat antar variabel tanpa adanya intervensi dari peneliti. Analisis ini menggunakan metode regresi linear berganda dengan bentuk persamaan:

$$
Y=\beta_{o}+\beta_{1} X_{1}+\beta_{2} X_{2}+\beta_{3} X_{3}+\beta_{4} X_{4}+\text { ei }
$$

Keterangan:

$\mathrm{Y}=$ Produksi (Rupiah)

$\mathrm{X} 0=$ Konstanta

$\mathrm{X}_{1}=$ Modal

$\mathrm{X}_{2}=$ Tenaga Kerja

$\mathrm{X}_{3}=$ Harga

$\mathrm{X}_{4}=$ Bahan Baku

ei = Residual ( unsur kesalahan pengganggu )

\section{Pengujian hipotesis}

Untuk menguji hipotesis yang memperlihatkan pengaruh variabel independen terhadap variabel dependen digunakan analisis linier berganda.

\section{Uji F}

Uji F pada dasarnya dimaksudkan untuk membuktikan secara statistik bahwa seluruh variabel independen berpengaruh secara bersama-sama terhadap variabel 
dependen yaitu probabilitas produksi kerupuk Desa Kota Harapan Kabupaten Tanjung Jabung Timur. Dengan hipotesis untuk menunjukkan apakah semua variabel bebas yang dimaksudkan dalam model mempunyai pengaruh secara bersama - sama terhadap variabel tak bebas.

\section{Uji t-statistik}

Uji statistik $\mathrm{t}$ dilakukan untuk menunjukkan seberapa jauh pengaruh satu variabel penjelas atau independen secara individual dalam menerangkan variasi variabel dependen (Imam Ghozali, 2005).

\section{Koefisien Determinasi $\left(\mathbf{R}^{\mathbf{2}}\right)$}

Koefisien determinasi $\left(\mathrm{R}^{2}\right)$ bertujuan untuk mengetahui seberapa jauh variasi variabel independen dapat menerangkan dengan baik variasi variabel dependen. Untuk mengukur kebaikan suatu model (goodness of fit) dengan mwnggunakan koefisien determinasi $\left(\mathrm{R}^{2}\right)$. Koefisien determinasi $\left(\mathrm{R}^{2}\right)$ merupakan angka yang memberikan proporsi atau presentase variasi total dalam variabel tak bebas (Y) yang di jelaskan oleh variabel bebas (X) (Gujarati, 2013).

\section{HASIL DAN PEMBAHASAN}

\section{Modal}

Modal disini yaitu sejumlah uang yang dikeluarkan pemilik usaha untuk memulai usaha. Setiap perusahaan atau industri selalu membutuhkan modal kerja untuk kebutuhan perusahaan ataupun industri. Jumlah dan persentase pemilik industri kerupuk udang berdasarkan modal dapat dilihat pada tabel berikut :

Tabel 1. Jumlah dan persentase responden berdasarkan modal

\begin{tabular}{ccc}
\hline Modal (Rupiah) & Jumlah (Responden) & Persentase (\%) \\
\hline $200.000-249.000$ & 7 & 22,58 \\
$250.000-299.000$ & 10 & 32,26 \\
$300.000-349.000$ & 7 & 22,58 \\
$\geq 350.000$ & 7 & 22,58 \\
\hline Jumlah & $\mathbf{3 1}$ & $\mathbf{1 0 0}$ \\
\hline
\end{tabular}

Sumber : Data diolah, 2019

Tabel 1 menjelaskan jumlah modal yang dikeluarkan oleh setiap pemilik industri kerupuk udang di Desa Lambur Luar. Dilihat dari tabel, pemilik industri kerupuk udang responden terbanyak yaitu pada modal antara 250.000 - 299.000 sebanyak 10 responden atau sebesar 32,26 pesen. Rata - rata modal yang dikeluarkan pemilik industri kerupuk udang yaitu sebesar 286.600 rupiah. Jika dilihat dari rata - rata jumlah modal pada pemilik industri kerupuk udang tidak terlalu besar. Hal ini karena rata - rata pemilik industri kerupuk udang bukan merupakan pekerjaan utama, melainkan hanya pekerjaan tambahan.

\section{Tenaga kerja}

Tenaga kerja merupakan suatu kebutuhan yang sangat diperlukan salam industri kecil ini. Tanpa adanya tenaga kerja tentunya proses produksi tidak akan berjalan dengan baik. Dengan adanya tenaga kerja kegiatan produksi akan cepat terselesaikan dengan baik, artinya faktor tenaga kerja sangat dibutuhkan dalam proses kegiatan 
produksi. Kegiatan produksi akan berhenti jika tenaga kerja yang diperlukan mengalami gangguan, sehingga berdampak pada penjualan yang akan diterima perusahaan atau industri tersebut. Banyaknya jumlah tenaga kerja pada industri kerupuk ini dapat dilihat sebagai berikut :

Tabel 2. Jumlah dan persentase responden berdasarkan jumlah tenaga kerja

\begin{tabular}{ccc}
\hline Tenaga Kerja (Orang) & Jumlah (Responden) & Persentase (\%) \\
\hline 2 & 8 & 25,81 \\
3 & 16 & 51,61 \\
4 & 7 & 22,58 \\
\hline Jumlah & $\mathbf{3 1}$ & $\mathbf{1 0 0}$ \\
\hline
\end{tabular}

Sumber : Data diolah, 2019

Berdasarkan tabel 2 yang telah diolah dapat disimpulkan bahwa responden industri kerupuk udang di Desa Lambur Luar sebagian besar menggunakan - tenaga kerja yang berjumlah 3 orang yaitu sebanyak 16 responden pemilik industri kerupuk udang atau 51,61 persen . Rata - rata tenaga kerja industri kerupuk udang yaitu sebesar 3,48 orang. Jumlah tenaga kerja masih tergolong kecil atau sedikit, hal ini dikarenakan industri kerupuk udang hanya menggunakan tenaga kerja sebagai pengupas udang, sedangkan untuk produksi menggunakan tenaga sendiri.

\section{Harga}

Harga merupakan sejumlah nilai yang ditukarkan konsumen dengan manfaat dari memiliki atau menggunakan produk atau jasa yang nilainya ditetapkan oleh pembeli atau penjual melalui tawar menawar, atau ditetapkan oleh penjual untuk satu harga yang sama terhadap semua pembeli. Harga kerupuk mempengaruhi jumlah produksi, karena konsumen akan mencari harga yang terendah dengan kualitas yang baik. Harga disini yaitu harga kerupuk udang perkilogram dalam satuan rupiah.

Tabel 3. Jumlah dan persentase responden berdasarkan harga kerupuk udang

\begin{tabular}{ccc}
\hline Harga (Rupiah) & Jumlah (Responden) & Persentase (\%) \\
\hline 58.000 & 8 & 25,81 \\
60.000 & 23 & 74,19 \\
\hline Jumlah & $\mathbf{3 1}$ & $\mathbf{1 0 0}$ \\
\hline
\end{tabular}

Sumber : Data diolah, 2019

Berdasarkan tabel 3 data primer yang diperoleh, harga kerupuk udang di Desa Lambur Luar tidak terlalu bervariasi, yaitu pada harga Rp.58.000 dan Rp.60.000. Tetapi jumlah responden terbanyak yaitu pada harga kerupuk Rp.60.000 sebanyak 23 responden atau sebesar 74,19 persen dari keseluruhan responden sebanyak 31. Dan sisanya yaitu pada harga Rp.58.000 sebanyak 8 responden. Banyaknya pemilik industri yang memberikan harga lebih tinggi dibandingkan 8 responden tersebut karena harga bahan baku yang mahal.

\section{Bahan baku}

Bahan baku disini merupakan jumlah bahan baku yang digunakan oleh pemilik indsutri dalam proses produksi kerupuk udang perbulannya dalam satuan rupiah. Bahan baku merupakan bahan yang membentuk bagian besar produk jadi. Bahan baku yang 
diolah dalam perusahaan manufaktur dapat diperoleh dari pembeli lokal, impor atau hasil pengolahan sendiri. Kegiatan produksi tidak akan terwujud dan terlaksana tanpa adanya alat atau benda yang digunakan untuk memproduksi suatu barang. Jadi diperlukan adanya faktor-faktor produksi untuk menciptakan, menghasilkan benda atau jasa. Berikut dibawah ini jumlah dan persentase responden berdasarkan bahan baku :

Tabel 4. Jumlah dan persentase responden berdasarkan bahan baku

\begin{tabular}{ccc}
\hline Bahan Baku (Rupiah) & Jumlah (Responden) & Persentase (\%) \\
\hline$\leq 1.999 .000$ & 1 & 3,22 \\
$2.000 .000-2.299 .000$ & 10 & 32,26 \\
$2.300 .000-2.599 .000$ & 8 & 25,81 \\
$2.600 .000-2.899 .000$ & 5 & 16,13 \\
$2.900 .000-3.199 .000$ & 3 & 9,68 \\
$3.200 .000-3.499 .000$ & 3 & 9,68 \\
$\geq 3.500 .000$ & 1 & 3,22 \\
\hline Jumlah & $\mathbf{3 1}$ & $\mathbf{1 0 0}$ \\
\hline
\end{tabular}

Sumber : Data diolah, 2019

Berdasarkan tabel 4 didapat bahwa jumlah bahan baku terbanyak yaitu pada angka Rp.2.000.000 - Rp.2.299.000 rupiah sebanyak 10 responden atau 32,26 persen. Sedangkan jika dilihat rata - ratanya yaitu sebesar Rp.2.578.065 rupiah. Dapat disimpulkan bahwa jika dilihat dari rata - rata jumlah uang yang dikeluarkan untuk membeli bahan baku tidak terlalu besar, hal ini memang dikarenakan bahan baku utama yaitu udang stoknya tidak terlalu banyak, jadi pemilik industri tidak menyediakan dalam jumlah banyak untuk bahan baku lainnya.

\section{Jumlah produksi}

Kapasitas produksi industri rumah tangga sangat bervariasi pada masing masing individu setiap pengusaha, yaitu ada yang berada pada tingkat produksi yang rendah, menengah dan tinggi. Jumlah pemilik industri berdasarkan tingkat kapasitas produksi dapat dilihat sebagai berikut :

Tabel 5. Jumlah produksi kerupuk udang

\begin{tabular}{ccc}
\hline Kapasitas Produksi/ bulan (Kg) & Jumlah(Responden) & Persentase (\%) \\
\hline $50-60$ & 18 & 58,06 \\
$61-70$ & 3 & 9,68 \\
$71-80$ & 7 & 22,58 \\
$81-90$ & 3 & 9,68 \\
\hline Jumlah & $\mathbf{3 1}$ & $\mathbf{1 0 0}$ \\
\hline
\end{tabular}

Sumber : Data diolah, 2019

Berdasarkan tabel 5 diatas, diketahui bahwa jumlah responden terbesar pada hasil produksi antara $50-60 \mathrm{~kg} / \mathrm{bulan}$ yaitu sebanyak 18 orang atau sebesar 58 persen dari seluruh jumlah pemilik industri kerupuk udang yang ada. Rata - rata produksi yang dihasilkan yaitu sebanyak 66,29 kilogram. Artinya pada industri kerupuk udang di Desa Lambur Luar masih tergolong sedikit dalam jumlah produksinya. Hal ini dikarenakan 
jumlah bahan baku utama yaitu udang yang terbatas karena banyaknya pemilik industri kerupuk udang yang mencari udang sebagai bahan baku utama dalam pembuatan kerupuk udang.

\section{Faktor - faktor yang mempengaruhi produksi pada industri rumah tangga}

Hasil regresi dalam penelitian ini untuk mengetahui besarnya pengaruh variabel Modal, Tenaga Kerja, Harga dan Bahan baku terhadap produksi pada industri rumah tangga kerupuk udang di Desa Lambur Luar. Untuk mengetahui besarnya koefisien regresi dari variabel Modal, Tenaga Kerja, Harga dan Bahan baku terhadap produksi dengan perbandingan antara probability ( $\mathrm{p}$-value) dan level of significanta $=5 \%(0,05)$. Dimana dapat dilihat dari koefisien masing - masing variabel yang menggunakan Eviews8. Maka diperoleh hasil Analisis Regresi Linear Berganda sebagai berikur:

Tabel 6. Hasil Regresi Linear Berganda

\begin{tabular}{lrlll}
\hline \hline \multicolumn{1}{c}{ Variable } & Coefficient & Std. Error & t-Statistic & Prob. \\
\hline \hline C & -11638590 & 2593804. & -4.487074 & 0.0001 \\
MODAL & 4.227138 & 0.935087 & 4.520584 & 0.0001 \\
TENAGAKERJA & 171404.0 & 45185.93 & 3.793305 & 0.0008 \\
HARGA & 181.4359 & 41.21326 & 4.402368 & 0.0002 \\
BAHANBAKU & 1.173209 & 0.115400 & 10.16642 & 0.0000 \\
\hline \hline & & & & \\
R -squared & 0.963460 & Mean dependent var & 3898710. \\
Adjusted R-squared & 0.957838 & S.D. dependent var & 757961.0 \\
S.E. of regression & 155635.1 & Akaike info criterion & 26.89511 \\
Sum squared resid & $6.30 E+11$ & Schwarz criterion & 27.12639 \\
Log likelihood & -411.8741 & Hannan-Quinn criter. & 26.97050 \\
F-statistic & 171.3852 & Durbin-Watson stat & 2.244537 \\
Prob(F-statistic) & 0.000000 & & & \\
\hline \hline
\end{tabular}

Sumber : Data diolah, 2019

Dari koefisien regresi maka model regresi dapat di sederhanakan sebagai berikut :

\section{$Y=-11638590+4.227138$ Modal +171404.0 TKerja +181.4359 Harga + 1.173209 BahanBaku}

Nilai konstanta $\alpha$ sebesar -11638590 artinya bahwa jika modal, tenaga kerja, harga dan bahan baku adalah nol atau tidak berubah maka tingkat produksi menurun sebesar 11638590 kilogram. Koefisien Modal pada Produksi kerupuk udang di Desa Lambur Luar sebesar 4.227138 persen artinya setiap kenaikan Modal sebesar 1 rupiah maka akan meningkatkan produksi sebesar 4.227138 kilogram. Koefisien Tenaga Kerja pada Produksi kerupuk udang di Desa Lambur Luar sebesar 171404.0 persen artinya setiap kenaikan tenaga kerja sebanyak 1 orang maka akan meningkatkan produksi sebesar 171404.0 kilogram. Koefisien Harga pada Produksi kerupuk udang di Desa Lambur Luar sebesar 181.4359 persen artinya setiap kenaikan harga sebesar 1 rupiah maka akan meningkatkan produksi sebesar 181.4359 kilogram. Koefisien Bahan baku pada Produksi kerupuk udang di Desa Lambur Luar sebesar 1.173209 persen artinya 
setiap kenaikan bahan baku sebesar 1 rupiah maka akan meningkatkan produksi sebesar 1.173209 kilogram.

\section{Uji hipotesis}

Uji f

Pengujian secara simultan (Uji f) di gunakan untuk melihat seberapa besar pengaruh variabel modal, tenaga kerja, harga dan bahan baku yang dimasukan dalam model berpengaruh secara signifikan terhadap produksi pada industri kerupuk udang di Desa Lambur Luar. Dengan membandingkan Prob(F-statistic) terhadap nilai alpha $5 \%=0.05$ maka dapat di ketahui ada tidaknya pengaruh variabel modal, tenaga kerja, harga dan bahan baku terhadap produksi pada industri kerupuk udang di Desa Lambur Luar.

\section{Uji t-statistik (parsial)}

\section{Modal}

Pada hasil regres menunjukkan bahwa pengujian koefisien regresi dengan menggunakan $\alpha=5 \%(0,05)$ variabel modal, dapat dilihat nilai $\mathrm{t}$ hitung sebesar 4.520584 dengan probabilitas variabel modal sebesar 0.0001 atau lebih kecil dari $\alpha=0.05(0.0001<0.05)$ maka $\mathrm{H} 0$ di tolak dan Ha diterima. Artinya variabel modal secara individual berpengaruh dan signifikan terhadap produksi pada industri kerupuk udang di Desa Lambur Luar.

\section{Tenaga kerja}

Pada hasil regres menunjukkan bahwa pengujian koefisien regresi dengan menggunakan $\alpha=5 \%(0,05)$ variabel tenaga kerja, dapat di lihat nilai t hitung sebesar 3.793305 dengan probabilitas variabel tenaga kerja sebesar 0.0008 atau lebih kecil dari $\alpha=0.05(0.0008<0.05)$ maka $\mathrm{H} 0$ di tolak dan Ha diterima. Artinya variabel modal secara individual berpengaruh dan signifikan terhadap produksi pada industri kerupuk udang di Desa Lambur Luar.

\section{Harga}

Pada hasil regres menunjukkan bahwa pengujian koefisien regresi dengan menggunakan $\alpha=5 \%(0,05)$ variabel harga, dapat dilihat nilai t hitung sebesar 4.402368 dengan probabilitas variabel harga sebesar 0.0002 atau lebih kecil dari $\alpha=0.05(0.0002<$ 0.05) maka H0 di tolak dan Ha diterima. Artinya variabel harga secara individual berpengaruh dan signifikan terhadap produksi pada industri kerupuk udang di Desa Lambur Luar.

\section{Bahan baku}

Pada hasil regres menunjukkan bahwa pengujian koefisien regresi dengan menggunakan $\alpha=5 \%(0,05)$ variabel bahan baku, dapat dilihat nilai $t$ hitung sebesar 10.16642 dengan probabilitas variabel bahan baku sebesar 0.0000 atau lebih kecil dari $\alpha=0.05(0.0000<0.05)$ maka H0 di tolak dan Ha diterima. Artinya variabel bahan baku secara individual berpengaruh dan signifikan terhadap produksi pada industri kerupuk udang di Desa Lambur Luar.

\section{Koefisien determinasi $\left(\mathbf{R}^{2}\right)$}


Koefisien determinasi digunakan untuk seberapa besar tingkat pengaruh variabel bebas yaitu ( modal, tenaga kerja, harga dan bahan baku ) terhadap variabel terikat yaitu ( produksi ). Hasil pengujian diperoleh nilai koefisien determinasi $\left(R^{2}\right)$ sebesar 0.963460. Hal ini menujukan modal, tenaga kerja, harga dan bahan baku mampu mempengaruhi produksi sebesar 96,34 persen dan sisanya 3,66 persen variabel lainnya yang tidak termasuk dalam penelitian ini.

\section{Uji asumsi klasik}

\section{Uji multikolinearitas}

Multkolinearitas merupakan salah satu model asumsi klasik yang melihat hubungan antara sesama variabel bebas. Pengujian multikolinearitas menggunakan Uji Variance Inflation Factors (VIF) dengan menggunakan sofrware Eviews8. Jika nilai VIF lebih besar dari 10 maka adanya gejala multikolinearitas.

Tabel 7. Hasil pengujian multikolinearitas

\begin{tabular}{cccc}
\hline \hline Variable & $\begin{array}{c}\text { Coefficient } \\
\text { Variance }\end{array}$ & $\begin{array}{c}\text { Uncentered } \\
\text { VIF }\end{array}$ & $\begin{array}{c}\text { Centered } \\
\text { VIF }\end{array}$ \\
\hline \hline C & $6.73 \mathrm{E}+12$ & 8610.350 & NA \\
MODAL & 0.874387 & 95.59256 & 3.674146 \\
TENAGAKERJA & $2.04 \mathrm{E}+09$ & 24.27637 & 1.261675 \\
HARGA & 1698.533 & 7693.303 & 1.664849 \\
BAHANBAKU & 0.013317 & 117.1353 & 3.856623 \\
\hline \hline
\end{tabular}

Sumber : Data diolah, 2019

Telihat bahwa dari tabel diatas menujukan hubungan variabel bebas dengan variabel bebas lainnya, nilai VIF lebih kecil dari 10 maka tidak adanya gejala multikolinearitas pada penlitian ini.

\section{Uji heterokedastisitas}

Pengujian heterokedastisitas digunakan untuk mengetahui ada atau tidaknya penyimpangan asumsi klasik. Pengujian heterokedastisitas melihat ketidaksamaan varian dari residual satu ke pengamatan model lainnya. Persyaratan harus di penuhi pada penelitian ini adalah probabilitas setiap variabel tidak signifikan agar terhindar dari gejala heterokedastisitas. Berikut hasil dan penjelasannya.

Tabel 8. Hasil Pengujian Heterokedastisitas

Heteroskedasticity Test: Breusch-Pagan-Godfrey

\begin{tabular}{llll}
\hline \hline F-statistic & 0.120557 & Prob. F(4,26) & 0.9739 \\
Obs*R-squared & 0.564496 & Prob. Chi-Square(4) & 0.9669 \\
Scaled explained SS & 0.473194 & Prob. Chi-Square(4) & 0.9761 \\
\hline
\end{tabular}

Sumber : Data diolah, 2019

Dari data diatas terlihat bahwa probabilita Chi-Square lebih besar dari nilai $\alpha$ yang di pilih yaitu sebesar $0,9669>0,05$ berarti tidak di temukan masalah heterokedastisitas atau terbebas dari gejala heterokedastisitas. 


\section{Uji autoKorelasi}

Uji autokorelasi bertujuan menguji apakah dalam model regresi linear ada korelasi atau hubungan antara kesalahan penganggu pada periode $t$ dengan kesalahan penganggu pada periode t-1. Maka digunakan uji Breusch-Godfrey untuk mengetahui apakah model yang digunakan terdapat autokorelasi di antara variabel-variabel yang diamati.

Tabel 9. Hasil pengujian autokorelasi

Breusch-Godfrey Serial Correlation LM Test:

\begin{tabular}{llll}
\hline \hline F-statistic & 1.535243 & Prob. F(2,24) & 0.2358 \\
Obs*R-squared & 3.516193 & Prob. Chi-Square(2) & 0.1724 \\
\hline \hline
\end{tabular}

Sumber : Data diolah, 2019

Berdasarkan tabel di atas dapat di ketahui hasil uji autokorelasi dengan menggunakan metode LM menujukan nilai probabilitas Chi-Square sebesar 0,1724 > 0,05 . Hal ini berarti tidak di temukan adanya masalah autokorelasi.

\section{Uji Normalitas}

Untuk menguji apakah data berdistribusi normal atau tidak maka dilakukan dengan menggunakan metode Jarque-Bera. Berikut hasil dan penjelasanya. Dari hasil gambar dapat diketahui dengan menggunakan metode jarque-bera di peroleh nilai probability sebesar $0.393421>0.05$ maka model di atas berdistribusi normal, dan terbebas dari gejala normalitas.

Gambar 1. Hasil pengujian normalitas

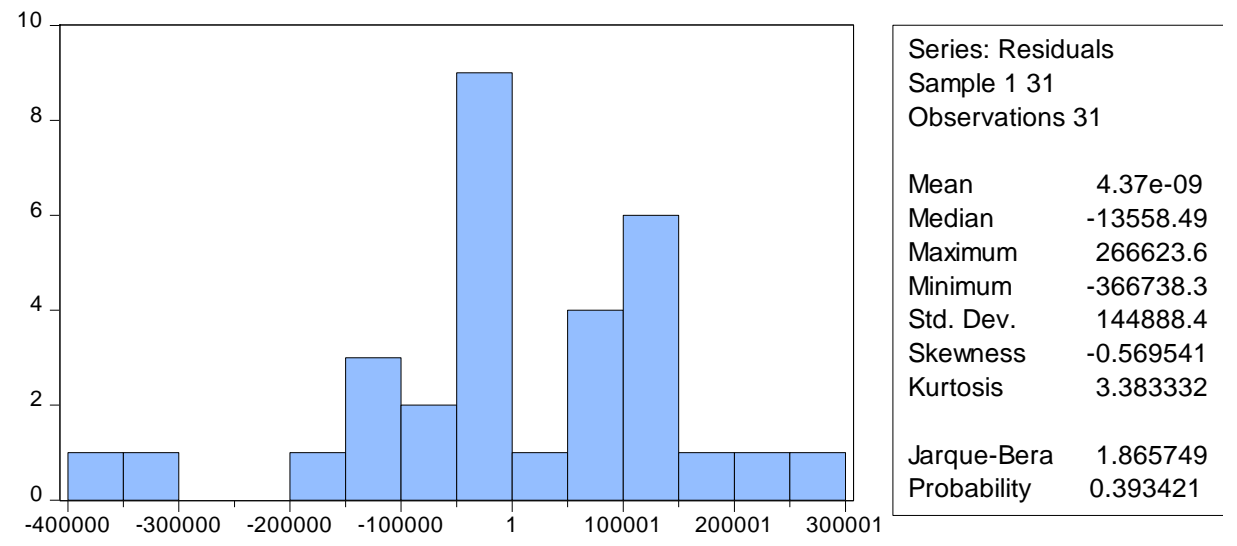

Sumber : Data diolah, 2019

\section{Implikasi hasil penelitian}

Dapat dilihat bahwa produksi industri kecil rumah tangga penting dalam peningkatan perekonomian suatu wilayah khususnya suatu daerah di Indonesia. Produksi industri rumah tangga yang tinggi menandakan terjadinya efisiensi dari industri yang melakukan proses manufaktur input, proses dan output sumber - sumber daya yang ada. Berdasarkan hasil penelitian ditemukan bahwa faktor - faktor produksi industri rumah tangga kerupuk udang di Desa Lambur Luar adalah modal, tenaga kerja, harga serta bahan baku. Hal ini mengandung implikasi agar dapat dilakukan peningkatan secara bersama - sama dari keempat faktor tersebut agar produksi industri rumah tangga kerupuk udang di Desa Lambur Luar dapat terus meningkat. 
Produksi pada industri rumah tangga menjadi motor penggerak pertumbuhan ekonomi indonesia. Beberapa kebijakan yang dapat dilakukan pemerintah untuk meningkatkan produksi industri rumah tangga adalah pemberian bantuan baik sosial maupun ekonomi. Salah satu bentuk bantuan sosial ekonomi yang telah pemerintah keluarkan adalah program kerjasama IKM di pasar modern, yaitu dengan memberikan kesempatan bagi pelaku usaha kecil itu untuk bepromosi sekaligus sebagai wahana edukasi.

Pemerintah Kota jambi telah menganggarkan untuk pembuatan website yang nantinya bisa dipakai untuk memasarkan produk IKM di Provinsi Jambi secara online (e-commerce). Pemerintah membuat program pemberian izin label halal kepada produk makanan dan minuman hasil industri rumah tangga, hal itu sangat penting karena memang selama ini pelaku IKM kesulitan memasarkan hasil produknya karena tidak adanya label dari MUI tersebut. Pemerintah akan mendorong pelaku UMKM untuk terus merambah pasar - pasar lain, bukan hanya di pasar modern, melainkan juga akan dipasarkan secara digital. Potensi IKM di Kota Jambi sangat besar sehingga perlu didorong baik dari segi pemasaran, pengemasan maupun secara pengolahan. Sehingga mampu diterima oleh pasar baik secara lokal maupun global. Dengan adanya program pemerintah seperti smart city juga nantnya produk IKM akan semakin banyak dikenal oleh masyarakat secara luas sehingga akan berdampak pula pada pelaku IKM itu sendiri.

Kabupaten Tanjung Jabung Timur merupakan pintu gerbang Provinsi Jambi yang terletak dan berada pada kawasan Pantai Timur Provinsi Jambi yang bersinggungan langsung dengan pusat kegiatan dalam pertumbuhan ekonomi sehingga mempunyai nilai SIJORI (Singapura, Johor, dan Riau) maupun SIBAJO (Singapura, Batam dan Johor) sehingga mempunyai nilai yang sangat strategis bagi pertumbuhan perekonomian regional khususnya bagi masyarakat di Kabupaten Tanjung Jabung Timur Provinsi Jambi serta pertumbuhan perekonomian global.

Selain itu, dalam mendukung pembangunan ekonomi Kabupaten Tanjung Jabung Timur yang merupakan pusat pemasaran bagi arus distribusi produk ekspor dan impor secara langsung akan berpengaruh terhadap sektor ekonomi lainnya. Oleh karena itu, penungkatan pembenahan, penataan dan pengembangan sarana dan prasarana bagi Industri Kecil Menengah (IKM) di Kabupaten Tanjung Jabung Timur perlu untuk dilakukan penataan dan pengembangan sehingga keberadaannya dapat mamacu peningkatan ekonomi masyarakat.

Pemerintah Kabupaten Tanjung Jabung Timur selalu berupaya meningkatkan pendapatan perekonomian masyarakat khusunya para pelaku IKM melalui kegiatan pembinaan berupa pelatihan, sosialisasi dan pembinaan langsung kepada para pengrajin. Pada tahun 2018 di Kabupaten Tanjung Jabung Timur telah terbentuk organisasi pengrajin IKM yang merupakan suatu wadah bagi para pengrajin untuk berkomunikasi dan bertukar informasi dalam rangka peningkatan kualitas dan pemasaran produk, selain itu juga organisasi tersebut sebagai perpanjangan tangan pemerintah daerah khsususnya intansi terkait dalan kegiatan pembinaan IKM.

\section{KESIMPULAN DAN SARAN \\ Kesimpulan}

Berdasarkan karakteristik sosial dan ekonomi industri kerupuk udang di Desa Lambur Luar Kecamatan Muara Sabak Timur Kabupaten Tanjung Jabung Timur :

Rata - rata umur pemilik industri kerupuk udang yaitu 41,09 tahun, rata - rata tingkat pendidikan pemilik industri kerupuk udang yaitu sebesar 10,06, rata - rata jumlah 
tanggungan keluarga pemilik industri kerupuk udang sebanyak 3 orang, rata - rata modal yang dikeluarkan pemilik industri kerupuk udang yaitu sebesar 286.600 rupiah, rata - rata tenaga kerja industri kerupuk udang yaitu sebesar 3,48 orang, rata - rata produksi yang dihasilkan yaitu sebesar 66,29 kilogram, rata - rata lama usaha yaitu 7,03 tahun, rata - rata pendapatan kotor yaitu Rp. 3.893.333 rupiah, rata - rata pendapatan bersih yaitu Rp.1.044.516 rupiah, rata - rata pendapatan keluarga yaitu Rp. .4 .372 .755 rupiah.

Dari hasil regresi diketahui bahwa varibael modal, tenaga kerja, harga dan bahan baku berpengaruh positif dan signifikan terhadap produksi pada industri kerupuk udang di Desa Lambur Luar.

\section{Saran}

Berdasarkan uraian kesimpulan diatas, maka penulis mempunyai saran ataupu masukan dilihat dari karakteristik sosial ekonomi responden tersebut bahwa para pemilik industri kerupuk udang di Desa Lambur Luar saat ini memerlukan perhatian dari pemerintah. Misalnya pemberian keterampilan dan pelatihan - pelatihan untuk peningkatan dan pengembangan usaha. Untuk para pemilik industri kerupuk udang perlu meningkatkan produksinya, serta terhadap produksi itu sendiri untuk mendapatkan nilai tambah (value added).

\section{DAFTAR PUSTAKA}

Aris, (2012). Teori Ekonomi Produksi, Brillian Internasional: Surabaya

Bangun, Wilson, (2010). Teori Ekonomi Mikro, PT.Refika Aditama: Bandung

Boediono, (2013). Ekonomi Mikro, BPFE :Yogyakarta

Elyas, Nurdin, (2004), Sukses Dengan Home Industry. Yogyakarta : Absolut

Ghozali, Imam, (2005). Aplikasi Analisis Multivate dengan SPSS. Badan Penerbit UNDIP: Semarang

Ginting, Perdana, (2009). Perkembangan Industri Indonesia: Menuju Negara Industri. Yrama Widya: Bandung

Gujarati, Damodar, (2013). Ekonomi Dasar. Erlangga: Jakarta

Hemnur Zulhriski, (2008). Analisis Pendapatan Pedagang Sayur Keliling di Kelurahan Tegallega Kota Bogor. Skripsi. IPB: Bogor

Kardiman, (2003). Ekonomi, Yudhistira: Jakarta

Kotler, Philip and Keller, Kevin Lane, (2012). Marketing Management. 14th edition. Prentice: New Jersey

Masiyal Kholmi, (2003). Akuntansi Biaya Edisi Empat, BPFE: Yogyakarta

Minto Purwo, (2000). Ekonomi, Yudhistira: Jakarta.

Rahardja, Prathama dan Mandala Manurung, (2008). Pengantar Ilmu Ekonomi. Lembaga Penerbit Fakultas EkonomiUniversitas Indonesia: Jakarta

Roger LeRoy, Miller, Roger E, Meiners, (2000). Teori Mikro Ekonomi Intermediate cetakan keempat edisi 1, Raja Grafindo Persada: Jakarta

Sukirno, Sadano, (2003). Pengantar Teori Mikro Ekonomi. Penerbit PT. Salemba: Jakarta

Sukirno, (2010). Pengantar Teori Makro Ekonomi, cetakan ke 19, Raja Grafindo Persada: Jakarta 